\title{
Comparative study of descendent colon rupture resistance considering traction force of rupture and total energy of rupture in rats ${ }^{1}$
}

\author{
Estudo comparativo da resistência de ruptura de cólon descendente por meio de \\ ensaio uniaxial força de ruptura à tração e energia total de ruptura em ratos
}

\author{
Feng Chung Wu², Huei Diana Lee ${ }^{3}$, Maksoel Algustin Krauspenhar Niz ${ }^{4}$, Maria de Loudes Setsuko Ayrizono ${ }^{5}$ Cláudio \\ Saddy Rodrigues Coy ${ }^{6}$, Juvenal Ricardo Navarro Góes ${ }^{7}$, João José Fagundes ${ }^{6}$ \\ 1. Study performed at the Coloproctology Service at the Surgical Techniques Laboratory from the Medicine and Experimental Surgery \\ Center - NMCE, University of Campinas - UNICAMP, Brazil. \\ 2. PhD, Research Assistant Professor of the Department of Surgery - Coloproctology Service, Faculty of Medical Sciences, UNICAMP. \\ Researcher of the Institute of Automation Technology and Informatics - ITAI. Assistant Professor of the Computer Science Course at \\ the State University of West Paraná - UNIOESTE, Brazil. \\ 3. PhD, Assistant Professor of the Computer Science Course and Coordinator of the Bioinformatics Laboratory - LABI, UNIOESTE, Brazil. \\ 4. Trainee at the Bioinformatics Laboratory - LABI, UNIOESTE, Brazil. \\ 5. PhD, Department of Surgery - Coloproctology Service, Faculty of Medical Sciences, UNICAMP, Brazil. \\ 6. PhD, Assistant Professor of the Department of Surgery - Coloproctology Service, Faculty of Medical Sciences, UNICAMP, Brazil. \\ 7. PhD, Associate Professor of the Department of Surgery, Chair of the Department of Surgery and Head of the Coloproctology Service, \\ Faculty of Medical Sciences, UNICAMP, Brazil.
}

\begin{abstract}
Purpose: To compare total energy of rupture and traction force of rupture tests within a rupture resistance study of descendent colon of rats. Methods: Twelve descendent colon segments of rats were considered to perform the study. For each one of the specimens, total energy of rupture and traction force of rupture necessary to promote colic wall burst were evaluated through the biomechanical total energy of rupture test using the Biomechanical Data Acquisition and Analysis System, version 2.0. Average, standard deviation, standard error of average and coefficient of variation were considered for analysis of results. Results: Traction force of rupture average, standard deviation, standard error of average and coefficient of variation were 380.05 gf, 98.74, 28.5 e 25.98\%, respectively while total energy of rupture presented average of 244.85 gf, standard deviation of 57.76, standard error of average of 16.67 and coefficient of variation of 23.59. Conclusion: Although, total energy of rupture considered a larger number of attributes to its calculation related to non-linear viscoelastic materials, such as colic wall, it presented a smaller coefficient of variation when compared to traction force of rupture, thus demonstrating to constitute a possible parameter to analyze intestinal resistance of rats.
\end{abstract}

Key words: Biomechanics. Colon, Descending. Animal Experimentation.

\section{RESUMO}

Objetivo: Comparação das grandezas físicas Energia Total de Ruptura e Força de Ruptura à Tração no estudo da resistência de ruptura do cólon descendente de ratos. Métodos: Doze segmentos de cólon descendente de ratos foram utilizados como corpos de prova. Por meio do Teste Biomecânico Energia Total de Ruptura, obteve-se, de cada espécime, a Força de Ruptura à Tração e a Energia Total de Ruptura necessárias para promover o rompimento da parede cólica. Com esses valores, calculou-se a média, o desvio padrão, o erro padrão e o coeficiente de variação, sendo esse último atributo usado para a comparação das grandezas físicas. Resultados: Os valores da média, do desvio-padrão, do erro-padrão e do coeficiente de variação da Força de Ruptura à Tração foram 380,05 gf, 98,74, 28,5 e 25,98\%, respectivamente. A Energia Total de Ruptura apresentou a média de 244,85 gf, o desvio-padrão de 57,76, o erro padrão de 16,67 e o coeficiente de variação de 23,59\%. Conclusão: A Energia Total de Ruptura, mesmo considerando em seus cálculos maior quantidade de atributos pertencentes aos materiais com propriedade viscoelástica não linear, tal qual a estrutura da parede cólica, apresentou menor coeficiente de variação em comparação com o coeficiente de variação da Força de Ruptura à Tração, demonstrando ser um possível parâmetro para a análise da resistência intestinal de ratos.

Descritores: Biomecânica. Cólon Descendente. Experimentação animal. 


\section{Introduction}

The intrinsic resistance of the colic wall has been focus of research with the objective of inferring, through its measurement, the efficiency of the intestinal healing. Many biomechanical tests, based on different physic-mechanical concepts, are used to achieve this purpose. Nevertheless, the most frequently used essays, for example, traction force $^{1,2}$, explosion pressure ${ }^{3}$ and tension preassure ${ }^{4,5}$ do not consider in their calculations fundamental attributes from biological materials such as elongation, elasticity, plasticelastic deformation and rupture time. In fact, these essays evaluate partially the colic segments behavior which present viscoelastic non-linear properties ${ }^{6,7}$. With the aim of including these attributes into the analysis, it was developed the Total Energy of Rupture test (ETR) based on the Universal Principle of Energy Conservation. This biomechanical test permits the mathematical analysis of the inherent properties of the intestinal segments after their submission to a variable force with the time ${ }^{8}$. In this work a comparative study between the physical largeness of Traction of Rupture, which presents uniaxial characteristic, and Total Energy of Rupture is proposed.

\section{Methods}

The Committee of Ethics in Animal Experimentation CEEA-IB-UNICAMP, approved procedures performed within this work according to the ethical principles adopted by the Brazilian College of Animal Experimentation - COBEA (Protocol n 598-1). Twelve male Wistar rats were obtained from the Bioterism Center - CEMIB/UNICAMP, weighing 300-350 grams raised under similar conditions. Each animal provided a four-centimeter proof body of descendent colon. These specimens were submerged into a Becker cup containing a $0.9 \%$ physiologic solution at 37-centigrade degrees and papaverine chloridrate at a 250 milligrams per liter concentration. This procedure was performed with the purpose of minimizing spasms caused by the manipulation of the colon segments. After 30 minutes, these segments were taken out of solution and were submitted to the Total Energy of Rupture biomechanical test. This test is composed by the following components (Figure 1):

1. Proof body (descendent colon segment) (Figure 1-a);

2. Precision balance Mettler-Toledo SB8000 (Figure 1-b);

3. Strength cell from the precision balance Mettler-Toledo SB8000 (Figure 1-c);

4. Serial port from the precision balance Mettler-Toledo SB8000 (Figure 1-d);

5. Traction system B.BRAUN 871.012 (Figure 1-e);

6. Serial communication cable (Figure 1-f);

7. Personal Computer with serial interface RS232 and the Biomechanical Data Acquisition and Analysis System, version 2.0 (SABI 2.0) (Figure 1-g);

8. Polygraph Siemens-Elema/Modelo 804 Mingograft (Figure 1-h);

9. Catheter Cannon $n^{\circ} 18$ with the light closed (Figure 1-i);

10. Catheter Cannon $n^{\circ} 18$ with the light open (Figure 1-j);

11. Triple-via plug attached at the supporter (Figure 1-k);

12. Plastic syringe $(10 \mathrm{ml})$, placed at the polygraph transducer (Figure 1-l).

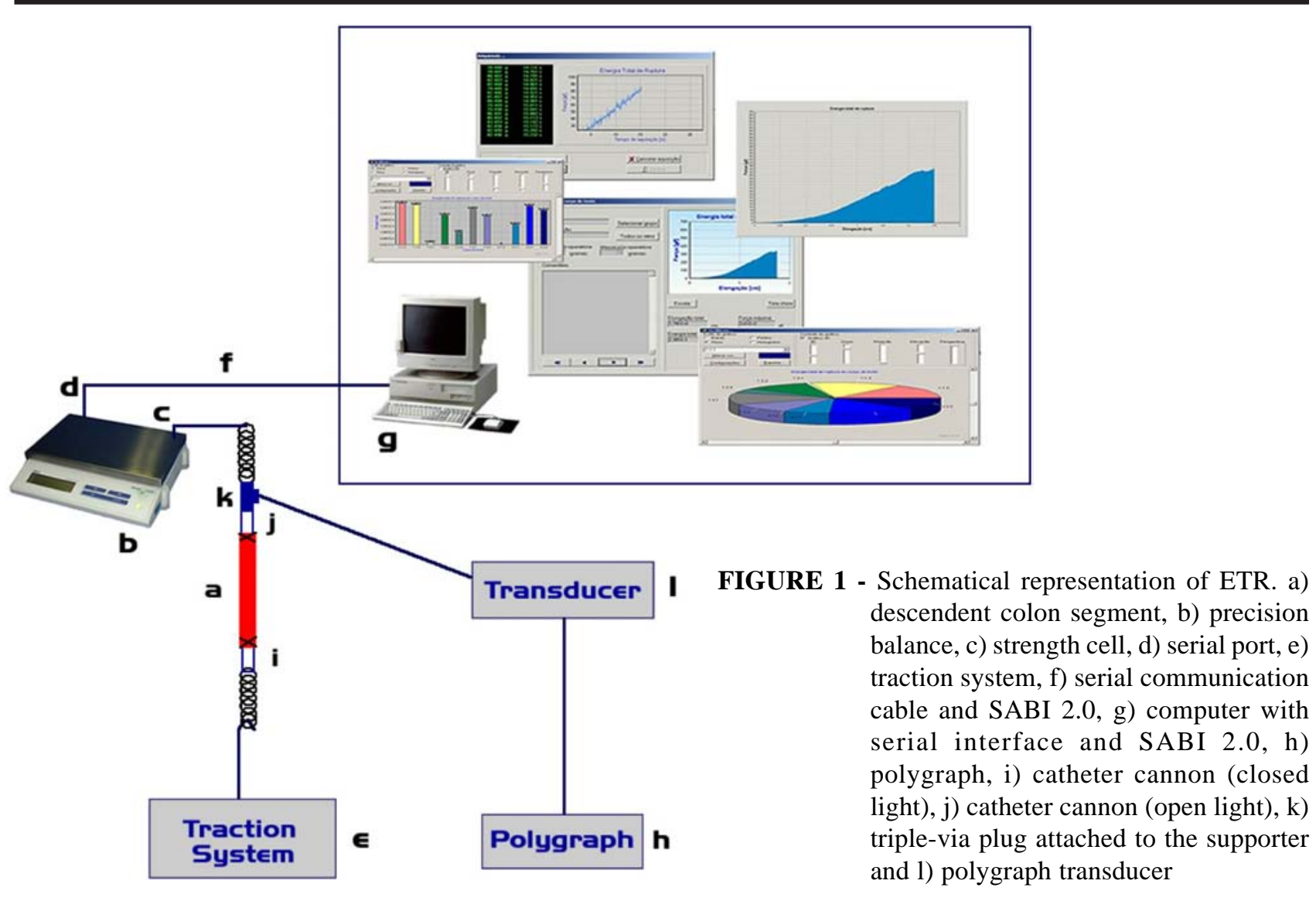


ETR test was performed following the protocol described by WU et al. ${ }^{8}$. The force generated by the traction system was transferred to the specimen and detected by the precision balance strength cell. The computer containing SABI 2.0 received the force values, at a rate of three packages of data per second, sent by the balance. This system, in real time, draws the graph of the function Force $x$ Elongation and, at the intestinal segment rupture moment, determines the Traction Force of Rupture value (FTR). SABI 2.0 automatically calculates the delimited area under this function through numerical integration using the Trapezoidal Rule method. This area corresponds to the Total Energy of Rupture (Figure 2)(Equation 1). A constant velocity of one centimeter per minute was maintained during the essay.

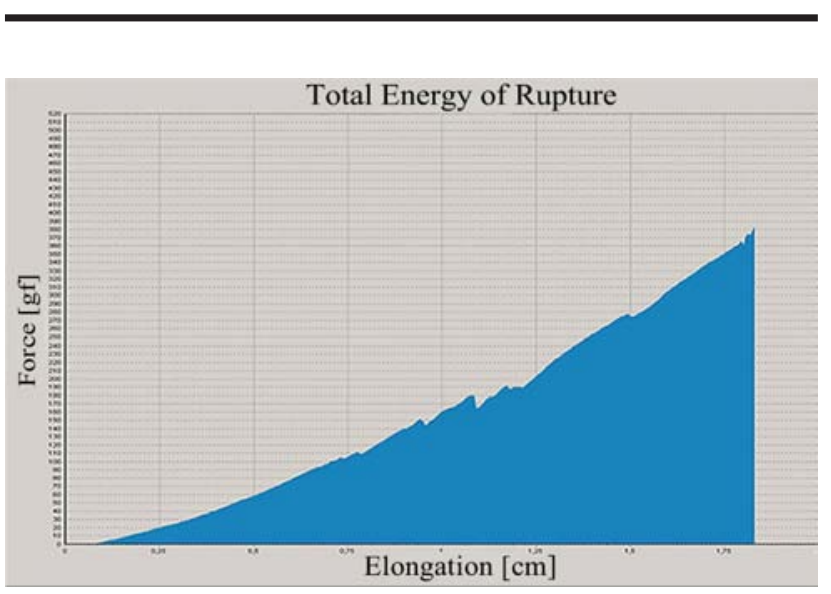

FIGURE 2 - Graph Force x Elongation of rupture. Maximal point of the ordinate represents the rupture force. The area under this function represents the total energy of rupture.

$\mathrm{ETR}=\int_{0}^{1} F(x) \cdot d x$

Equation (1)

Where $l$ represents the maximal elongation, $l_{0}$ the initial length, $F(x)$ the force corresponding to the elongation $x$ and $x$ the elongation which varies from $l_{0}$ to $l$.

Both Rupture Force and Total Energy of Rupture were obtained for each specimen through the ETR biomechanical test. Average, standard deviation, standard error of the average and variation coefficient of these two physical largeness were calculated and used for comparison.

\section{Results}

FRT and ETR values for each rat as well as average, standard deviation, standard error of the average and the variation coefficient from these physical largeness are presented at Table 1.

TABLE 1 - FRT and ETR values for each specimen. Average, standard deviation, standard error of the average and variation coefficient of FRT and ETR.

\begin{tabular}{lcc}
\hline RAT & FRT (gf) & ETR (gf . cm) \\
\hline R1 & 501.5 & 294.5 \\
R2 & 255.7 & 181.4 \\
R3 & 343.7 & 254.9 \\
R4 & 394.7 & 198.6 \\
R5 & 428.9 & 221.9 \\
R6 & 409.5 & 287.7 \\
R7 & 404.0 & 250.4 \\
R8 & 395.9 & 280.9 \\
R9 & 174.6 & 116.9 \\
R10 & 289.3 & 244.2 \\
R11 & 496.1 & 280.4 \\
R12 & 466.8 & 326.4 \\
\hline AVERAGE & 380.05 & 244.85 \\
Standard Deviation & 98.74 & 57.76 \\
Standard Error & 28.50 & 16.67 \\
\hline Variation Coefficient (\%) & $\mathbf{2 5 . 9 8}$ & $\mathbf{2 3 . 5 9}$ \\
\hline
\end{tabular}

\section{Discussion}

Severe problems are caused by the extravasation of the colic intraluminal content into the abdominal cavity leading to expressive indexes of morbidity and mortality ${ }^{1,2,3,4,5,9}$. Due to this fact, researchers have developed and applied different experimental models based on distinct physical-mechanical concepts with the aim to evaluate the intrinsic resistance of the intestinal wall when it is submitted to some kind of physical largeness ${ }^{1-11}$. The most used biomechanical essays are Traction Force of Rupture, Distension Pressure of Rupture using Liquid or Air and Tension of Rupture. On the one hand uniaxial tests, for example Traction Force of Rupture ${ }^{2,5}$ and Distension Pressure of Rupture ${ }^{3,4,10}$, and biaxial tests, such as Tension of Rupture ${ }^{2}$ and Final Resultant Tension of Rupture ${ }^{5}$, analyze partially the intestinal wall resistance properties, as these biological materials present non-linear viscoelastic properties. Therefore, essential attributes like deformation, time of rupture and elasticity module are not taken into account to calculate these physical largeness ${ }^{6,12}$.

On the other hand, it is believed that the Total Energy of Rupture, which corresponds to the accumulated inner energy necessary to promote the rupture of the intestinal loop, is able to analyze the resistance of intestinal segments. The Total Energy of Rupture is based on the Universal Principle of Energy Conservation and is obtained by applying the biomechanical ETR test, which considers for its calculation fundamental attributes and concepts related to the intestinal structure ${ }^{7,8}$. The ETR test, by means of 
SABI 2.0, draws in real time, the Force $x$ Elongation function. As a consequence, at the rupture moment, the maximal force corresponds to the Traction Force of Rupture while the area under this function (Force $\mathrm{x}$ Elongation) represents the Total Energy of Rupture, which is automatically calculated by SABI 2.0. Physical largeness of FRT and ETR were measured for each proof body which were considered for a unique biomechanical essay. ETR and FRT are measured in different units, gram-force per centimeter (gf.cm) and gram-force (gf), respectively. Hence, the variation coefficient, which does not depend on the unit of the measure, as it is numerically expressed through the division of the standard deviation by the average, was used to promote the comparison between both physical largeness. It permits the comparison of data dispersion, i.e., the smaller the variation coefficient the more homogeneous is the sample ${ }^{13}$. In this work, FRT and ETR were calculated considering the same proof bodies and showed similar homogeneity, presenting respectively variation coefficients of 25.98 and 23.29\%. Thus ETR exhibited a 2\% smaller value than FRT. Nevertheless, the Total Energy of Rupture, when compared to the FRT, considers a larger number of attributes for its calculation that pertain to materials with non-linear viscoelastic properties, therefore demonstrating to be a possible parameter to analyze the intestinal resistance of rats. Future studies shall include the evaluation of samples containing a larger amount of specimens and also the evaluation of other tissues that present non-linear viscoelastic properties.

\section{Conclusion}

In this study, the Total Energy of Rupture (ETR) presented a variation coefficient similar to the variation coefficient of Traction Force of Rupture (FRT), though ETR considers for its calculation a larger number of attributes that are related to materials with non-linear viscoelastic properties such as the structure of the colic wall.

\section{References}

1. Hermann JB, Woodward SC, Pulaski EJ. Healing of colonic anastomoses in the rat. Surg Gynecol Obstet. 1964;119:169-75.

2. Jiborn $\mathrm{H}$, Ahonem J, Zederfeldt B. Healing of experimental colonic anastomoses. II. Breaking strength of the colon after left colon resection and anastomosis. Am J Surg. 1978;136:595-9.
3. Wu FC, Ayrizono MLS, Fagundes JJ, Coy CSR, Góes JRN, Leonardi LS. Estudos biomecânicos da ação de aderências sobre anastomose cólica: trabalho experimental em ratos. Acta Cir Bras. 2003;18(3):216-23.

4. Aprilli F, Guimarães AS, Rocha JJR. Anastomoses intestinais. In: Silva Jr., O.C. Modelos experimentais de pesquisa em cirurgia. 1ed. São Paulo: Robe Editorial; 1998.

5. Wu FC. Estudo da ação de aderências sobre anastomose cólica: trabalho experimental em ratos [Dissertação - Mestrado]. Faculdade de Ciências Médicas da UNICAMP; 2000.

6. Fung YC. Biomechanics - Mechanical properties of soft living tissues. 2ed. New York: Spring-Verlag Inc; 1993.

7. Wu FC. Estudo dos efeitos de diferentes concentrações de oxigênio e da hiperoxigenação hiperbárica sobre anastomoses cólicas comprometidas ou não pela isquemia: trabalho experimental em ratos [Tese - Doutorado]. Faculdade de Ciências Médicas da UNICAMP; 2003.

8. Wu FC, Lee HD, Machado RB, Dalmas S, Coy CSR, Góes JRN, Fagundes JJ. Apresentação do teste energia total de ruptura para avaliação de material biológico com propriedade viscoelástico não-linear. Acta Cir Bras. 2004;19(6):609-16.

9. Fagundes JJ. Estudo comparativo da cicatrização de anastomoses cólicas realizadas com auxílio do bisturi laser de dióxido de carbono: trabalho experimental em cães [Tese - Doutorado]. Faculdade de Ciências Médicas da UNICAMP; 1999.

10.Hendricks T, Mastboom WJB. Healing of experimental intestinal anastomosis. Parameters for repairs. Dis Colon Rectum. 1990;33:891-901.

11.Souza Filho ZA, Ioshii SO, Greca FH, Biondo-Simões, MLP, Rocha SL, Duda JR, Oliveira Filho HR. Emprego da submucosa de intestino delgado porcina no reparo de lesões do esôfago cervical. Estudo experimental em cães. Acta Cir Bras. 2003;18(3):224-31.

12.Jamison CE, Marangoni RD, Glaser AA. Viscoelastic properties of soft tissue by discrete model characterization. $\mathrm{J}$ Biomechanics. 1968;1:33-46.

13.Freedman D, Pisani R, Purves R. Statistics. 3ed. New York: W.W. Norton \& Company, Inc., 1998.

\section{Acknowledgments}

To Ana Cristina de Moraes and William Adalberto Silva from the Medicine and Experimental Surgery Center (NMCE), University of Campinas (UNICAMP) for technical support.

\section{Correspondence:}

Bioinformatics Laboratory - LABI

State University of West Paraná - UNIOESTE

Rua Tarqüínio Joslin dos Santos, 1300

85870-650 Foz do Iguaçu - Paraná Brazil

Phone: (55 45)3520-5917

Fax: (55 45)3522-3462

wufc@unioeste.br
Conflict of interest: none Financial source:

Instituto de Tecnologia em Informática e Automação/ITAI

Received: October 11, 2005

Review: November 10, 2005

Accepted: December 12, 2005

\section{How to cite this article:}

Wu FC, Lee HD, Niz MAK, Ayrizono MLS, Coy CSR, Góes JRN, Fagundes JJ. Comparative study of descendent colon rupture resistance considering traction force of rupture and total energy of rupture in rats. Acta Cir Bras. [serial on the Internet] 2006 Mar-Apr;21(2). Available from URL: http://www.scielo.br/acb 